\title{
A Severe Accident Caused by an Ocellate River Stingray (Potamotrygon motoro) in Central Brazil: How Well Do We Really Understand Stingray Venom Chemistry, Envenomation, and Therapeutics?
}

\section{Nelson Jorge da Silva Jr. ${ }^{1,3}$, Kalley Ricardo Clementino Ferreira ${ }^{2}$, Raimundo Nonato Leite Pinto ${ }^{3,4}$ and Steven Douglas Aird ${ }^{5, *}$}

1 Programa de Pós-Graduação em Ciências Ambientais e Saúde, Pontifícia Universidade Católica de Goiás, Rua 232 n $^{\circ} 1283^{\circ}$ andar-Área V. Setor Universitário, CEP 74605-140 Goiânia, Goiás, Brazil; E-Mail: nelson.jorge.silvajr@gmail.com

2 Faculdade de Ciências Médicas do Instituto de Pesquisa e Ensino Médico - IPEMED, Rua Dr. Nogueira Martins no 706, Saúde, CEP 04143-020 São Paulo, São Paulo, Brazil; E-Mail: kalley.ferreira@me.com

3 Departamento de Medicina, Pontifícia Universidade Católica de Goiás, Avenida Universitária, 1069-Setor Universitário, CEP 74605-010 Goiânia, Goiás, Brazil;

E-Mail: raimundo58@gmail.com

4 Hospital de Doenças Tropicais Dr. Anuar Auad. Rua SC-1 nº 299, Parque Santa Cruz, CEP 74860-270 Goiânia, Goiás, Brazil

5 Evolution and Ecology Unit, Communications and Public Relations Division, Okinawa Institute of Science and Technology Graduate University, 1919-1 Tancha, Onna-son, Kunigami-gun, Okinawa 904-0495, Japan

* Author to whom correspondence should be addressed; E-Mail: steven.aird@oist.jp; Tel.: +81-98-966-1627; Fax: +81-98-966-112.

Academic Editor: Wayne Hodgson

Received: 13 May 2015 / Accepted: 30 May 2015 / Published: 18 June 2015

Abstract: Freshwater stingrays cause many serious human injuries, but identification of the offending species is uncommon. The present case involved a large freshwater stingray, Potamotrygon motoro (Chondrichthyes: Potamotrygonidae), in the Araguaia River in Tocantins, Brazil. Appropriate first aid was administered within $\sim 15 \mathrm{~min}$, except that an ice pack was applied. Analgesics provided no pain relief, although hot compresses did. Ciprofloxacin therapy commenced after $\sim 18 \mathrm{~h}$ and continued seven days. Then antibiotic 
was suspended; however, after two more days and additional tests, cephalosporin therapy was initiated, and proved successful. Pain worsened despite increasingly powerful analgesics, until debridement of the wound was performed after one month. The wound finally closed $\sim 70$ days after the accident, but the patient continued to have problems wearing shoes even eight months later. Chemistry and pharmacology of Potamotrygon venom and mucus, and clinical management of freshwater stingray envenomations are reviewed in light of the present case. Bacterial infections of stingray puncture wounds may account for more long-term morbidity than stingray venom. Simultaneous prophylactic use of multiple antibiotics is recommended for all but the most superficial stingray wounds. Distinguishing relative contributions of venom, mucus, and bacteria will require careful genomic and transcriptomic investigations of stingray tissues and contaminating bacteria.

Keywords: stingray envenomation; Potamotrygon motoro; treatment; antibiotics; venom chemistry; pharmacology

\section{Introduction}

Freshwater stingrays are elasmobranchs belonging to the monophyletic Family Potamotrygonidae, Garman, 1877. Descendants of Pacific and Caribbean marine stingrays [1], potamotrygonids exhibit considerable diversity in South America [2-8]. They are currently classified into four genera: Paratrygon (Duméril, 1865), Potamotrygon (Garman, 1877), Plesiotrygon (Rosa, Castello and Thorson, 1987), and Heliotrygon [9]. The Genus Potamotrygon is the most diverse, with more than 25 species identified to date [6,9-13]. Potamotrygonid stingrays occur in most river basins that drain into the Atlantic Ocean, including the Amazon-Orinoco, the Paraguay-Paraná, the Uruguay, and the Parnaíba River basin in northeastern Brazil [3,6,14-18].

Diurnally, stingrays partially bury themselves in sand or mud in shallow portions of rivers and lakes, where they feed mainly on small invertebrates and fish [10,19,20]. Stingrays possess one to three barbed stingers in the mid-distal region of the tail. These are covered with secretory cells that produce various proteins having nociceptive, inflammatory, and necrotic actions [14]. In addition, stingrays, like other fish, are covered with mucus. Even though the mucus contains elements of the non-specific immune system, it also harbors bacteria of many types. The stingers, with their associated secretory cells and mucus, constitute the only physical defensive weapon of these fishes [6,21-28]. They have no offensive or prey-capture function.

South American freshwater stingrays cause a large number of serious human injuries. These are common on the feet, ankles, and distal parts of the leg when people accidentally step on them, but because captured rays tend to thrash violently, fishermen also commonly suffer injuries to the hands and arms [6,7,21,23]. In central Brazil, the Tocantins and Araguaia River basins (subsystems of the Amazon-Orinoco basin) are heavily used for recreational activities, especially from June to August. Being the dry season, low water levels leave exposed beaches that attract tourists, and during this season stingray accidents are most common. 
In stingray envenomations, the mechanical injury itself is excruciatingly painful and usually causes considerable damage, owing to the retrorse serrations of the stingers, which sometimes cause trauma to major nerves and blood vessels [23,29-33]. The physical damage is exacerbated by the action of substances present in the mucus and the secretory epithelium covering the stingers. Secondary bacterial infections involving gram-negative species are common [34,35]. Serious morbidity and mortality are especially common in rural areas where medical attention is not readily available and patients do not seek treatment until symptoms become severe. Prompt and intensive cleansing of the wound, tetanus prophylaxis, and appropriate antibiotics are crucially important [36-38]. Domingos et al. [34] reported that antibiotic resistance of bacteria associated with stingray mucus is common, especially to ampicillin, amoxycillin/clavulanic acid, and cephalotin; $23 \%$ of their bacterial isolates were resistant to all but one of the sixteen antibiotics they tested. In addition to extreme nociception, stingray envenomations often involve edema, inflammation, and myotoxicity, while hemorrhagic and hemolytic activities are absent [24]. Severe envenomations involving delayed medical treatment or clinical mismanagement can result in amputation or death [38,39].

Potamotrygon motoro (Müller and Henle, 1841 [18]), the ocellate river stingray, is one of the most common stingray species in the Tocantins-Araguaia river basin, and has one of the broadest geographic distributions of any species in the genus. Despite the number of epidemiological studies of stingray envenomations, positive identification of the stingray species involved is quite rare [38]. In this paper, we report a severe human accident involving an ocellate river stingray in central Brazil and we discuss implications for public health strategies related to freshwater stingray envenomations. What makes this case unusual is that the victim, one of the co-authors of this report, was raised in the region where the accident occurred. He is an ardent fisherman familiar with fish of the local rivers. When shown photographs of various rays, marine and freshwater, Brazilian and foreign, he unhesitatingly identified the offending species. Moreover, he is also a physician. Accordingly, the resulting case report is the most detailed of which we are aware.

\section{Case Report}

On 20 July 2014, at approximately 12:30 pm, a 41-year-old Caucasian male was stung by a freshwater stingray along a beach of the Araguaia River, known as Praia do Pontão (municipality of Santa Fé do Araguaia) in the northwestern region of the state of Tocantins, Brazil (Figure 1). While bathing in shallow water at the beach, the subject felt something under the sand, but before he could react, he was stung on the medial face of the left foot. The victim, despite the stress of the situation, was able to spot and carefully observe the stingray. It was an adult ocellate river stingray (Potamotrygon motoro) approximately $60 \mathrm{~cm}$ in width (across the body disk) (Figure 2). 


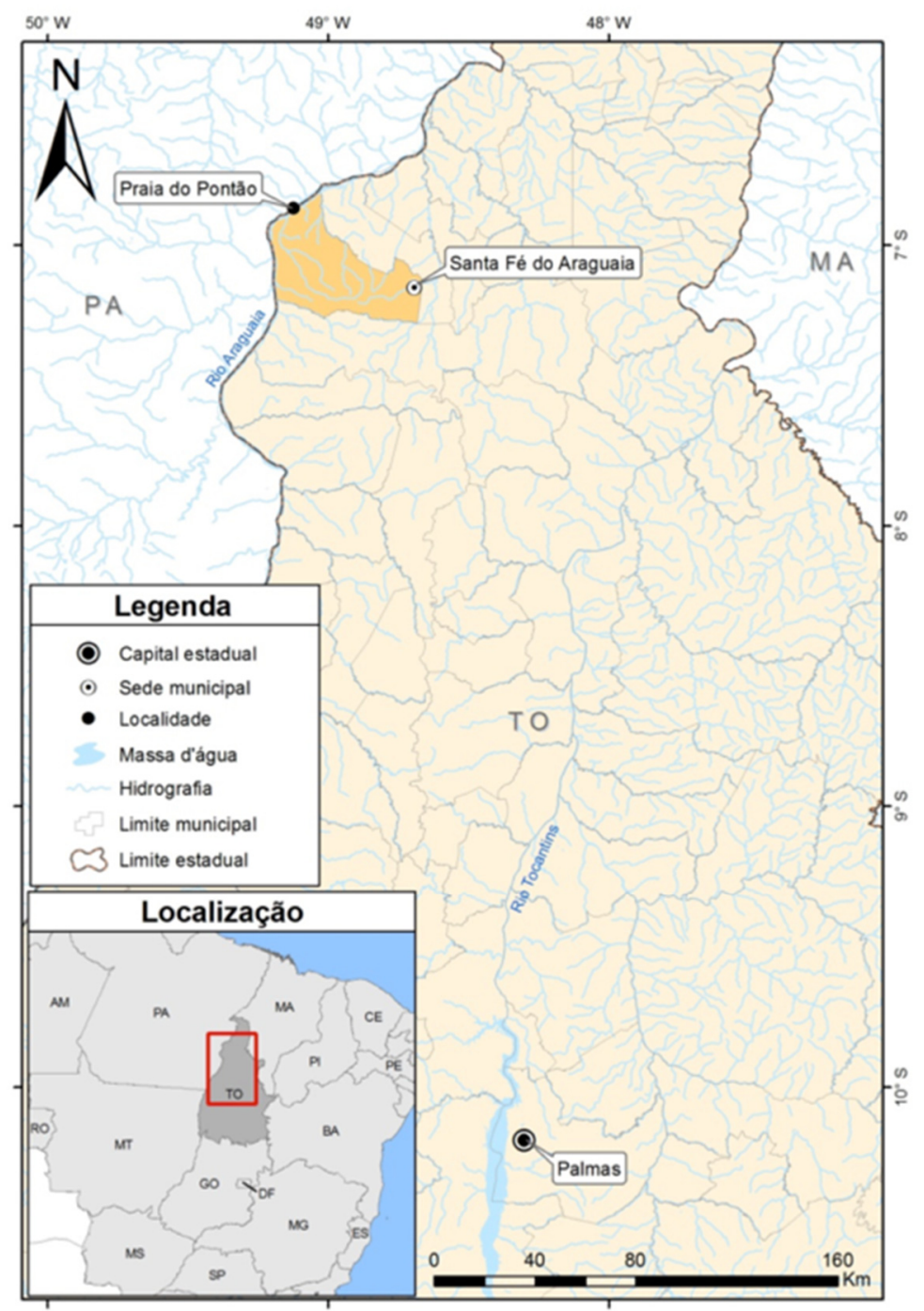

Figure 1. Map showing the location of the stingray accident in northwestern Tocantins state with landmarks mentioned in the text. Drawing: Sérgio Henrique de Moura Nogueira (2015).

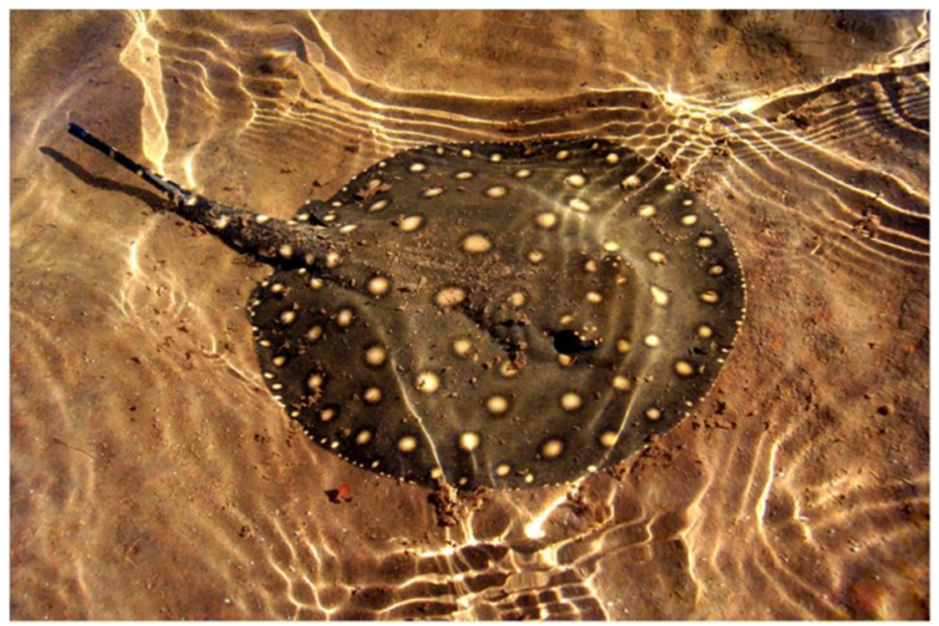

Figure 2. An adult ocellate river stingray (Potamotrygon motoro) from the Araguaia-Tocantins basin. Photo: Itamar Júnior Tonial (2013). 
The accident resulted in a deep puncture wound with copious bleeding and excruciating pain that quickly spread to the distal part of the thigh. Reaching a local first aid station 10 min after the accident, the wound was cleaned with Povidone iodine and the patient received $3 \mathrm{~mL}$ of $2 \%$ Xylocaine subcutaneously, and $1.5 \mathrm{~g}$ Paracetamol (acetaminophen), a non-steroidal, anti-inflammatory (Diclofenac Potassium, $75 \mathrm{mg}$ ), and an ampyrone sulfonate analgesic, antispasmodic, and antipyretic Dipyrone ( $1 \mathrm{~g}$ ) orally. At that time, an ice compress was applied and the victim was transported by boat to the nearest village $(40 \mathrm{~min})$ and then by car $(2 \mathrm{~h})$ to the town of Santa Fé do Araguaia (Figure 1). Admitted to a local hospital, the victim received an ampoule of analgesic (Tramadol Hydrochloride, $100 \mathrm{mg}$ ) and a synthetic opioid analgesic (Meperidine, $100 \mathrm{mg}$ ) i.v.; however, these did not reduce the pain. By this time, edema and erythema were strongly evident. The site of the wound was extremely sensitive to touch, and the pain had radiated to the upper left thigh. Inguinal lymph nodes on the left side were visible enlarged with the first signs of peripheral vasculitis (Figure 3A). Only at this point was the patient informed that the ice compress was inappropriate. It was replaced with hot compresses, which caused the local pain to subside within a $3 \mathrm{~h}$ period.

On 21 July, the patient was transported by car to Palmas, the capital city of Tocantins, an $11 \mathrm{~h}$ trip (Figure 1). During this journey, clinical symptoms worsened considerably, with increased edema and pain (Figure 3B). In a hospital environment, the wound was again cleaned with Povidone and the patient received another 3-mL dose of $2 \%$ Xylocaine subcutaneously. Antibiotic therapy was initiated approximately $18 \mathrm{~h}$ after the injury and analgesic and anti-inflammatory medications were changed. The patient received the antibiotic (Ciprofloxacin, $500 \mathrm{mg}$ ) plus a non-steroidal, anti-inflammatory (Ketoprofen, $50 \mathrm{mg}$ ), and Tramadol Hydrochloride $(50 \mathrm{mg}$ ), each three times a day. He remained at Palmas $48 \mathrm{~h}$ before being transferred to São Paulo, where he resides. During this period the edema began to subside, while the intense local and radiating pain persisted (Figure 3C).

On 24 July, the patient was transferred to São Paulo by air. Once again in a hospital environment, the patient was attended to by a vascular surgeon, who requested a blood count and imaging exams (x-ray, tomography and echo-doppler). The results revealed a peripheral vascular lesion and evident leukocytosis (12,500 leukocytes/mL; 92\% neutrophils; elevated Protein C). Medication started on 21 July was continued. However, the pain was not alleviated. The patient started to walk using crutches. On 27 July, with no fever or signs of local infection, antibiotics were suspended, (Figure 3D). However, on 29 July, after repeating all laboratory tests, antibiotic therapy was reinitiated, this time with a beta-lactam antibiotic (Cephalosporin, $2 \mathrm{~g}, i . v$.) once a day, for seven days (until 4 August) with the persistence of pain and worsening of the local lesion (Figure 3E).

The period from 5-20 August comprised the most serious phase of the local lesion with vasculitis and tissue necrosis. On 5 August, the patient received Tramadol Hydrochloride $(3 \times 50 \mathrm{mg} /$ day $)$, $200 \mathrm{mg}$ of a medication for neuropathic pain (Carbamazepine, $3 \times 200 \mathrm{mg} / \mathrm{day}$ ), and thiamine $(1 \times 300 \mathrm{mg} /$ day $)$ on suspicion of peripheral neuropathy. With still worsening pain, this protocol was changed to include Ketoprofen $(1 \times 150 \mathrm{mg} /$ day), Oxycodone $(2 \times 10 \mathrm{mg} / \mathrm{day})$, and Clexane (low MW heparin) (1 injection s.c. $\times 60 \mu \mathrm{g})$ every $24 \mathrm{~h}$. The latter was given in consequence of the patient's vasculitis. This regimen was maintained until 17 August (Figure 3F). The patient was also given Zolpidem (10 mg/day) for two months to treat insomnia. Interestingly, during this period the patient began to experience significant symptoms of anxiety. He was given escytalopram (10 mg/day) and 
cognitive behavioral therapy was initiated. Therapy continued until the end of November, but escytalopram was continued until March, 2015.

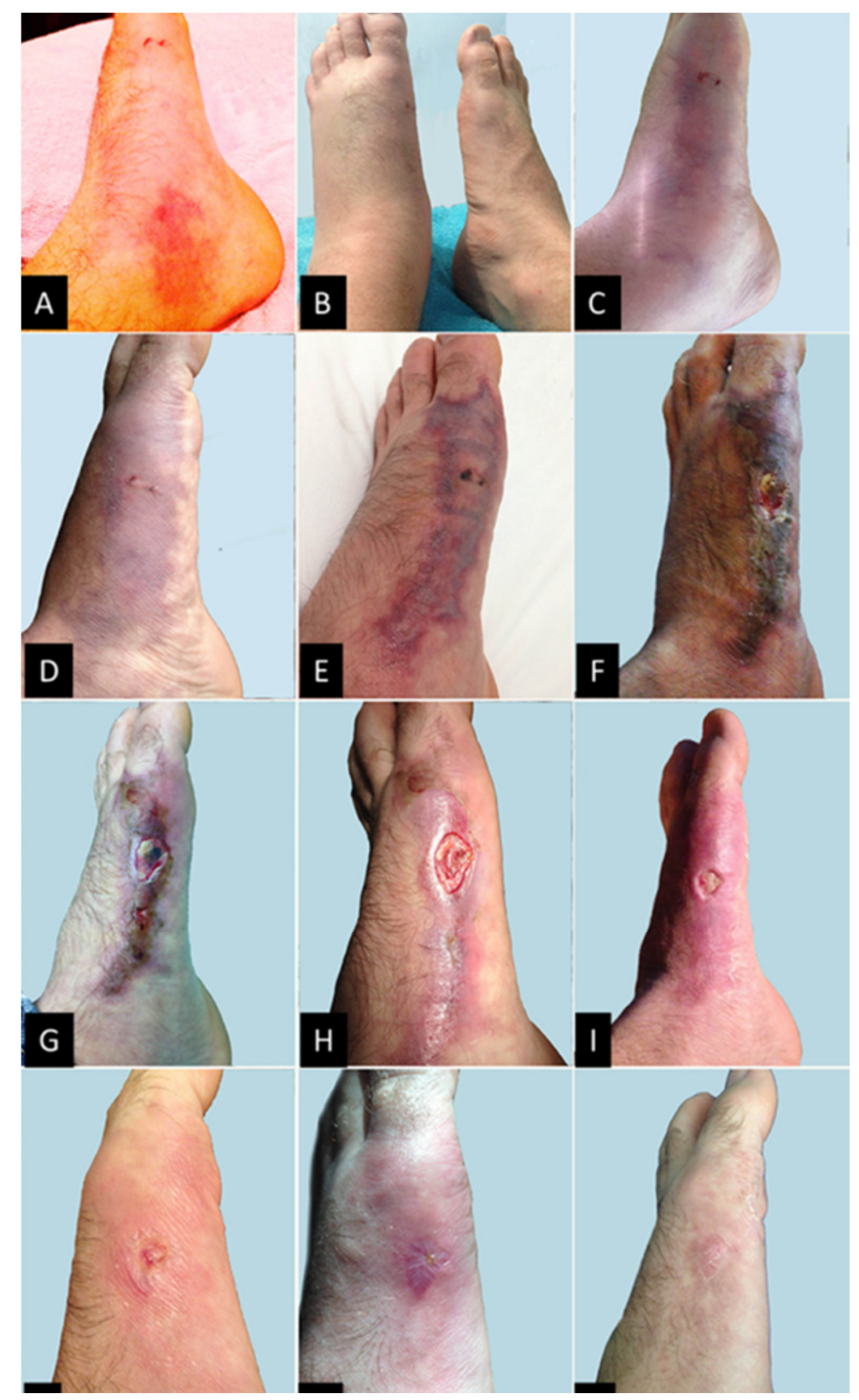

Figure 3. Evolution of the accident caused by an ocellate river stingray (Potamotrygon motoro) from the first day to complete healing of the wound: A. Evident edema with vasculitis and hyperemia caused by the trauma of sting penetration with laceration of tissues, and by the action of proteolytic enzymes that damage cells and liberate fluid and cellular debris into the interstices; B. Worsening of edema $24 \mathrm{~h}$ after the accident; C. Evident ecchymosis and prevailing edema; D. Worsening of ecchymosis; E. Ecchymosis with evident initial local necrosis; F. Dry necrosis of the affected area with evident dead tissue; G. Replacement of necrotic tissues with granulation tissue, although with areas of dead tissue; H. Total replacement of necrotic area with granulation tissue and evident recovery; I. Accelerated granulation of the affected area with only the focal trauma remaining open; J. to $\mathbf{L}$. Total recovery of tissues and regeneration of the traumatized area. 
On 19 August, debridement of the wound was performed, which subsequently decreased the pressure and pain (by 21 August). Pain medications were changed accordingly. At this point the patient received only Ibuprofen (600 mg) and Paracetamol (750 mg) as needed (Figure 3G,H). On 21 August, the wound started to granulate along the margin. Bandages with SAF-Gel and Kollagenase topical cream $(0.6 \mathrm{U} / \mathrm{g})$ were applied every other day. After five days, the peripheral vasculitis persisted without any advance in granulation. Significant local pain and functional incapacitation of the left leg required the continued use of crutches. The left foot became increasingly painful when touched (Figure 3I).

Beginning on 9 September, bandages with topical Phenytoin cream (4\%) were changed once a day. The healing process (cicatrization) accelerated significantly and the wound closed completely between 20 and 30 September, when the patient started to move without the aid of crutches (Figure 3J,K). The region around the wound was still sensitive to touch as of 1 March 2015, and the patient continued to have problems wearing closed shoes (Figure 3L).

\section{Discussion}

There have been relatively few biochemical characterizations of freshwater stingray venoms. Regarding potamotrygonid venoms, Rodrigues (p. 683) [40] declared that, "The chemical nature of the active principle is unknown, and our knowledge gathered from previous research is of dubious significance". More than 40 years later, it is probably still safe to say that we know more about what these venoms are not, than what they are. Marine stingray venoms have been somewhat better characterized than those of their freshwater cousins [21,41], but until very recently that was not saying much [24].

Understandably, stingray venoms share more attributes with fish venoms generally than with those of other vertebrates or invertebrates. However, they are difficult to characterize because they are not produced in a gland with a central lumen, but rather as a layer of secretory cells on external spines. Additionally, stingray venoms are mucus-rich, chemically unstable, and are adversely affected by heat and $\mathrm{pH}$. They lose activity with increasing storage time, freezing and thawing, and even lyophilization [42].

How similar potamotrygonid venoms are to those of marine rays is also unclear. The most thorough characterization of any ray venom to date is a transcriptomic and proteomic study of Neotrygon kuhlii venom by Baumann et al. [41]. Venom proteins with identified functions that are probably pertinent to envenomation include galectin, two cystatins, and peroxiredoxin-6. They did not find orpotrin or porflan (Potamotrygon orbignyi) [43,44], although they did manage to isolate a hyaluronidase gene; however, it was not present in the venom proteome, so they concluded that it was not actually a venom protein. They did not indicate whether it was of vertebrate or bacterial origin. Accidents caused by freshwater stingrays also tend to be more serious than those caused by marine rays [23]. Taken together, these reports suggest that characterizations of marine ray venoms may offer limited insights into the chemistry and pharmacology of freshwater ray venoms.

\subsection{Characterizations of Potamotrygon Venoms}

Rodrigues [40] isolated a compound from Potamotrygon motoro stings that contracted guinea pig ileum and produced a lethal vasodilation in rats. He concluded that the active constituent is non-proteinaceous, non-lipidic, water-insoluble, thermostable, and parasympathomimetic. Centrifuging 
the solution caused a significant reduction in activity of the supernatant, suggesting that the active principle was suspended, rather than dissolved.

Specialized cells of the Potamotrygon stinger epithelium stain well with bromophenol blue, indicating a high-protein content [25], but it is not clear that this material comprises active constituents of the venom. Given that the "venom" collected actually consists of cellular contents, much of the protein demonstrated in protein assays [45] may be irrelevant to biological activity assays performed. While Halstead [21] opined that venom-producing cells would be of a holocrine type, Pedroso et al. [25] found no evidence that these cells are capable of releasing material to the environment. They postulated instead that when the stinger enters the victim's tissues, mechanical abrasion probably shears and ruptures the venom-producing cells into the victim's tissues.

Magalhães detected 5'-nucleotidase, phospholipase, acid phosphatase, hyaluronidase, caseinolytic, gelatinolytic and elastinolytic activities in P. motoro venom from animals collected in the Crixás-Açú River (Goiás, Brasil) [46]. Haddad et al. [23] similarly reported hyaluronidase, caseinolytic, gelatinolytic and elastinolytic activities in P. falkneri venom. The latter authors [23] noted that $P$. falkneri venom has a major component with a mass of $\sim 12 \mathrm{kDa}$. SDS PAGE showed seven components between 80-200 kDa. Components with masses of 80+ and $100 \mathrm{kDa}$ displayed gelatinolytic and caseinolytic activities, respectively. Hyaluronidase activity was also present and was attributed to a protein of $\sim 84 \mathrm{kDa}[23,24,38]$.

Magalhães et al. [26] characterized the hyaluronidase isolated from the venom of $P$. motoro, with an estimated molecular weight of $79 \mathrm{kDa}$. Interestingly, they reported that $97 \%$ of the hyaluronidase activity was lost during gel filtration. If bacteria account for much of the hyaluronidase activity, they probably would have been filtered out by the gel. The enzyme was thermolabile, losing $70 \%$ of its activity when incubated for $30 \mathrm{~min}$ at its thermal optimum of $40{ }^{\circ} \mathrm{C}$ [26].

Potamotrygon venoms are well known to be nociceptive [45], but the compounds responsible are unknown. Heating of $P$. orbignyi and $P$. scobina venoms to $56^{\circ} \mathrm{C}$ reduced nociceptive activity by only $32 \%-34 \%$ and edematogenic activity by $16 \%-25 \%$ of their respective levels at $37{ }^{\circ} \mathrm{C}$ [45].

Conceição et al. [43] reported the presence of a vasoconstrictive nonapeptide (orpotrin) from the venom of Potamotrygon orbignyi. It transiently reduced the diameter of mouse cremaster muscle arterioles by about $65 \%$, with peak activity being seen approximately $20 \mathrm{~min}$ after injection. Later, Conceição et al. [44] sequenced and characterized an 18-residue pro-inflammatory peptide from venom of $P$. orbignyi. Named Porflan, it showed no similarity to any known peptide. Porflan and synthetic analogs did not affect arteriolar diameter or vascular permeability, but promoted leucocyte recruitment and adhesion in mouse microcirculation. More recently, Conceição et al. [47] also reported the presence of an antimicrobial protein $(\sim 16 \mathrm{kDa})$ with strong homology to the $\beta$-chain of hemoglobin. It had broad-spectrum activity against gram-negative and gram-positive bacteria and yeast, and it also exhibited minor pro-inflammatory activity. Kirchhoff et al. [48] found that adult $P$. leopold $i$ venoms have $\sim 5$-fold lower protein concentrations than juvenile venoms and that the adult venoms exhibited 10-fold lower cytotoxicity. Since stingray venoms are employed solely for self-defense, they attributed this to reduced predation pressure on adults. 


\subsection{Components Responsible for the Pharmacology of Stingray Venom and Mucus}

Mucus from external surfaces of bony fishes contains a number of immune components such as lysozyme, immunoglobulin, complement, carbonic anhydrase, lectins, crinotoxins, calmodulin, C-reactive protein, proteolytic enzymes, and antimicrobial peptides (Alexander \& Ingram, 1992). These probably function primarily in immune defense against bacteria and fungi. Mucus that covers the external surfaces of stingrays may be similar in composition and function. If so, any functions that the mucus serves in envenomation may be fortuitous.

There have been few attempts to characterize the pharmacology of stingray mucus. The most thorough study to date is that of Monteiro-dos-Santos et al. [49], who reported that both venom and mucus from the sting, and mucus from the skin of $P$. henlei, augmented vascular permeability and promoted nociception in mice, in essentially the same way as venoms and mucus of $P$. orbignyi and $P$. scobina. In both assays, the venom-mucus mixture from the sting was slightly more potent than mucus alone from the body of the ray. However, stingray mucus is well populated with bacteria and probably with some fungi as well [34-36,50-52]. Monteiro-dos-Santos et al. [49] do not appear to have filtered their solutions so as to remove bacteria, but we are unaware of any studies that have. This raises some interesting and clinically important questions, since many activities ascribed to stingray venom are extracellular enzymatic activities associated with bacterial species present in South American rivers and/or in stingray mucus [53].

- What biochemical components are produced by stingrays specifically to serve as toxins?

- To what extent do cytoplasmic components of stingray venom-producing cells contribute, if at all, to early symptoms of stingray envenomation?

- Does stingray mucus itself possess pharmacological activity relevant to envenomation?

- Why is the pain caused by freshwater stingray envenomations so intractable and persistent?

- What non-mucoid components of mucus, if any, are produced by bacteria in the mucus, rather than by the stingrays themselves?

- To what degree do bacteria in the mucus and in the water contribute to the sequelae of stingray envenomation?

It will not be possible to answer these questions conclusively without careful transcriptomic and genomic studies of both stingray venom-producing cells and bacteria present in stingray mucus. Clinically, the last question may be the most important, as the current case report suggests.

\subsection{Clinical Treatment of the Patient}

Proper treatment for stingray envenomations remains poorly understood and somewhat controversial within the Brazilian medical community. There are even anecdotal reports of anti-Bothrops antivenin being administered in some cases due to the pain and inflammation presented by stingray victims. This is unquestionably ineffective. The recommended therapeutic approach employs analgesics and anti-inflammatory drugs, immersion of the injured body part in hot water for pain relief, and antibiotics to prevent bacterial septicemia, gangrene, and tetanus [23,27,28,37]. In the present case, different treatment regimens were employed at different stages of the case, some more effective than others. 
Ice compresses were applied for approximately the first $3 \mathrm{~h}$. This treatment has been employed in some other cases [54,55], but as early as 1956, Russell and Lewis [56] concluded that heating the wound helped to control pain. Russell et al. [57] reported that packing the wound in ice actually intensified it. They concluded that venom components were thermolabile and that heating the injured appendage was beneficial therapeutically, a finding supported by others, with the caveat that it be done as soon as possible $[37,38,58,59]$. In this case also, upon arrival at the hospital in Santa Fé do Araguaia, hot compresses caused the pain to gradually subside. Magalhães et al. [45] reported partial inactivation of nociceptive and edematogenic activity of two Potamotrygon venoms at $56{ }^{\circ} \mathrm{C}$, and Haddad Jr. et al. [38] recommended immersion in $60{ }^{\circ} \mathrm{C}$ water! This is too hot, a concern also expressed by Meyer [59], who recommended that the bath be only as hot as the patient can stand. However, the reduction in activity of venom components at physiologically tolerable temperatures would be significantly less than that reported by Magalhães et al. [45]. Meyer acknowledged the prompt relief from pain afforded by immersion in hot water but suggested that inhibition of venom components may be less significant than the direct anti-nociceptive effects of heat. This could be true; however, since Magalhães et al. [45] heated the venom itself, rather than affected tissue, there is some direct effect as well.

The prompt onset and the extreme persistence of intractable pain induced by stingray venoms are difficult to explain. While these venoms are well known to be nociceptive, the nociceptive compounds have not been identified, nor have possible pharmacological mechanisms been proposed. While peptidyl toxins or chemical mediators of inflammation, such as histamine, could induce pain almost immediately, they would probably be cleared in due course and the pain they induced would likely not persist for extended periods. Chemistry and pharmacology of the stingray mucus itself are unknown, but again, it seems likely that the mucus would soon be degraded by various hydrolases. While purely hypothetical at this point, perhaps the most reasonable explanation would be some form of physically or chemically induced nerve damage.

Within two hours of the envenomation, the patient manifested edema, erythema, and the first signs of vasculitis. It would not be surprising if $P$. motoro venom contains a homolog to the pro-inflammatory peptide reported from $P$. orbignyi venom by Conceição et al. [44], but the mechanical damage and the introduced stingray mucus, toxins, cellular debris, and bacteria would also have provoked the release of chemical mediators of inflammation. It is therefore difficult to assess how much of a contribution such a venom peptide might make to the overall picture.

We are unaware of any other reports of insomnia or anxiety associated with stingray envenomation. If purely psychological in origin, such symptoms would logically be expected immediately after the event. However, in this case, onset was almost a full month after envenomation. This suggests a possible biochemical basis for such effects, but there are no clues in the envenomation literature regarding possible causes.

Significantly, in the present case, no antibiotics were administered for approximately $18 \mathrm{~h}$ after the injury, despite the well-documented occurrence of pathogenic bacteria and fungi in stingray venom and mucus, and in aquatic environments generally [34]. Given that secondary bacterial infections involving gram-negative species are common, this may have been a serious oversight. Such infections have been attributed to Aeromonas hydrophila, Aeromonas sobria, Pseudomonas aeruginosa, P. putida, Citrobacter freundii, Escherichia coli, Enterobacter cloacae, Photobacterium damsela, and 
Vibrio alginolyticus [34,35]. Clostridium perfringens, C. tetani, Pasteurella sp., Group A Streptococcus and Staphylococcus sp. have also been reported [29,36]. These infections often involve tissue necrosis, gangrene, tetanus, and septic shock, with extreme cases leading to death. Most of the gram-negative species are found in both river water and mucus of the barb epithelium; however, some bacteria have been detected only in mucus (Pseudomonas aeruginosa, Acinetobacter sp., Klebsiella pneumoniae, and some gram-positives) [34].

The first antibiotic employed was ciprofloxacin. Aeromonas hydrophila, one of the primary species responsible for bacterial infections of freshwater stingray wounds, is normally susceptible to ciprofloxacin; however, resistant strains have been documented in leeches [60] and in wastewater [61]. Resistance has also been reported in other bacteria common to stingray mucus, including Pseudomonas aeruginosa [62], Staphylococcus aureus [62,63], Klebsiella pneumoniae and Escherichia coli [64], Acinetobacter sp. [65], and Clostridium perfringens [66]. Ciprofloxacin and other medications commenced in Palmas were continued in São Paulo for a total of seven days. At that time, the patient manifested no fever and showed no signs of infection, so ciprofloxacin was discontinued. However, two days later, despite the lack of fever, additional lab tests showed elevated C-reactive protein (an indicator of inflammation that activates the complement system) and white blood cell counts. Accordingly, antibiotic therapy was resumed for another seven days, this time with cephalosporin.

The failure of ciprofloxacin therapy is not surprising, given the variety of bacterial species likely to be injected in a typical envenomation, and given the finding of Domingos et al. [34] that $23 \%$ of all bacterial isolates from stingray mucus and river water were resistant to all but one of 16 antibiotics tested. As an added caution, ciprofloxacin and other fluoroquinolones can cause peripheral neuropathy that may be irreversible, such as weakness, burning pain, tingling, or numbness [67-69]. In rare cases, such symptoms, should they occur, might be overlooked or misattributed to the envenomation itself. While cephalosporin therapy ultimately proved successful, resistance to this antibiotic is also well known in various bacterial species pertinent to Potamotrygon envenomations: Citrobacter freundii [70-72], Pseudomonas aeruginosa, Aeromonas hydrophila, Enterobacter, Acinetobacter sp., Klebsiella pneumoniae [72-74]. Given the practice of using the same antibiotic classes for both human and veterinary applications and indiscriminate uses of antibiotics, it is virtually certain that antibiotic resistance will become increasingly problematic [72].

When the patient in the present case arrived in São Paulo, skin was starting to slough near the margins of the wound, a condition that has also been reported in Potamotrygon falkneri envenomations [28]. Schechter [75] reported that the basement membrane of the dermal-epidermal junction is highly susceptible to degradation by neutral proteases released by inflammatory cells. Elastase and Type IV collagenase were the most efficient at destroying the basement membrane, but trypsin- and chymotrypsin-like proteases were also capable of doing this. Gelatinases (metalloproteases) as well as collagenase have been implicated in epidermal detachment [76].

Neither of these activities has been directly linked to stingray venom; however, if not produced by mast cells or other inflammatory cells in the wound, such activity certainly could have been bacterial in origin. Collagenase activity has been reported in Streptococcus pyogenes and S. mutans [77,78], various Clostridium species [79-82], Pseudomonas aeruginosa [83,84], and Vibrio alginolyticus [85-89], being especially prominent in the latter two species. Gelatinase activity has also been reported in bacterial 
species present in stingray envenomations: Aeromonas hydrophila, Aeromonas sobria, Pseudomonas aeruginosa [34], and Vibrio alginolyticus [89], and also in Streptococcus pyogenes [77].

\section{Conclusions and Future Directions}

Given that stingray envenomations usually involve puncture wounds in aquatic environments, except in cases involving only superficial lacerations, we think it advisable to use prophylactic antibiotic treatment. Moreover, in view of the diversity of bacteria likely to be involved in a single accident and the frequency of antibiotic resistance among bacterial species present in stingray mucus and in tropical aquatic habitats, it would be wise to administer combinations of broad-spectrum antibiotics, including those effective against species of Clostridium.

Future studies undertaken to better characterize stingray venoms need to control for bacterial contamination of venom and mucus samples. In particular, pharmacological activity of the mucus itself needs to be carefully investigated. Even proteins isolated from mucus and venom cannot simply be assumed to originate with the stingrays themselves. Because they may be secreted bacterial proteins, the biological origins of proteins in stingray mucus need to be identified. This will necessitate genomic and transcriptomic studies of both stingray tissues and bacteria.

\section{Acknowledgments}

NJSJr is supported by a grant from the Conselho Nacional de Desenvolvimento Científico e Tecnológico (CNPq) - Process 309443/2013-0.

\section{Author Contributions}

K.R.C. made the most significant contribution by obligingly stepping on the stingray, without which there would have been no study. He also recorded the case history and took the photographs of his foot during treatment and recovery. N.J.S. and S.D.A. reviewed the literature, analyzed the data, and wrote the manuscript. R.N.L.P. reviewed the case history, assessed the development and healing of the wound, and wrote the descriptions for Figure 3. All authors edited the manuscript.

\section{Conflicts of Interest}

The authors declare no conflict of interest.

\section{References}

1. Lovejoy, N.R. Stingrays, Parasites, and Neotropical Biogeography: A Closer Look at Brooks et al/s Hypotheses Concerning the Origins of Neotropical Freshwater Rays (Potamotrygonidae). Syst. Biol. 1997, 46, 218-230.

2. Thorson, T.B.; Brooks, D.R.; Mayes, M.A. The evolution of freshwater adaptation in stingrays. Natl. Geogr. Soc. Res. Rep. 1983, 15, 663-694.

3. Rosa, R.S. A Systematic Revision of the South American Freshwater Stingrays (Chondrichthyes, Potamotrygonidae); The College of William and Mary: Williamsburg, VA, USA, 1985. 
4. Lovejoy, N.R. Systematics of myliobatoid elasmobranchs with emphasis on the phylogeny and historical biogeography of Neotropical freshwater stingrays (Potamotrygonidae: Rajiformes). Zool. J. Linn. Soc. 1996, 117, 207-257.

5. Lovejoy, N.R.; Albert, J.S.; Crampton, W.G.R. Miocene marine incursions and marine/freshwater transitions: Evidence from Neotropical fishes. J. S. Am. Earth Sci. 2006, 21, 5-13.

6. Carvalho, M.R.; Lovejoy, N.R.; Rosa, R.S. Family Potamotrygonidae. In Checklist of the Freshwater Fishes of South and Central America; Reis, R.E., Ferraris, C.J., Jr., Kullander, S.O., Eds.; EDIPUCRS: Porto Alegre, Rio Grande do Sul, Brazil, 2003; pp. 22-29.

7. Carvalho, M.R.; Maisey, J.G.; Grande, L. Freshwater stingray of the Green River Formation of Wyoming (Early Eocene), with description of a new genus and species and an analysis of its phylogenetic relationships (Chondrichthyes: Myliobatiformes). Bull. Am. Mus. Nat. Hist. 2004, 284, $1-136$.

8. Hoorn, C.; Wesselingh, F.P.; ter Steege, H.; Bermudez, M.A.; Mora, A.; Sevink, J.; Sanmartin, I.; Sanchez-Meseguer, A.; Anderson, C.L.; Figueiredo, J.P.; et al. Amazonia through time: Andean uplift, climate change, landscape evolution, and biodiversity. Science 2010, 330, 927-931.

9. Carvalho, M.R.; Lovejoy, N.R. Morphology and phylogenetic relationships of a remarkable new genus and two new species of Neotropical freshwater stingrays from the Amazon basin (Chondrichthyes: Potamotrygonidae). Zootaxa 2011, 48, 13-48.

10. Rosa, R.S.; Charvet-Almeida, P.; Quijada, C.C.D. Biology of the South American Potamotrygonid stingray. In Sharks and Their Relatives II: Biodiversity, Adaptative Physiology and Conservation; Carrier, J.C., Musick, J.A., Heithaus, M.R., Eds.; CRC Press: Boca Raton, FL, USA, 2010; pp. 241-286.

11. Carvalho, M.R.; Perez, M.H.S.; Lovejoy, N.R. Potamotrygon tigrina, a new species of freshwater stingray from the upper Amazon basin, closely related to Potamotrygon schroederi FernandezYépez, 1958 (Chondrichthyes: Potamotrygonidae). Zootaxa 2011, 2827, 1-30.

12. Silva, J.P.C.B.; Carvalho, M.R. A new species of Neotropical freshwater stingray of the genus Potamotrygon Garman, 1877 from the Río Madre de Díos, Peru (Chondrichthyes: Potamotrygonidae). Pap. Avulsos Zool. 2011, 51, 139-154.

13. Fontenelle, J.P.; da Silva, J.P.; de Carvalho, M.R. Potamotrygon limai, sp. nov., a new species of freshwater stingray from the upper Madeira River system, Amazon basin (Chondrichthyes: Potamotrygonidae). Zootaxa 2014, 3765, 249-268.

14. Rosa, R.S.; Carvalho, M.R. Familia Potamotrygonidae. Catálogo das Espécies de Peixes de Água Doce do Brasil; Museu Nacional: Rio de Janeiro, Brazil, 2007.

15. Soares, E.C. Peixes do Mearim; Editora Geia: São Luís, Maranhão, Brazil, 2005.

16. Garman, S. The Plagiostoma (sharks, skates and rays). Mem. Mus. Comp. Zool. 1913, 36, 1-515.

17. Compagno, L.J.V.; Cook, S.F. The exploitation and conservation of freshwater elasmobranchs: Status of taxa and prospects for the future. J. Aquaricult. Aquat. Sci. 1995, 7, 62-90.

18. Loboda, T.S.; Carvalho, M.R. Systematic revision of the Potamotrygon motoro (Müller \& Henle, 1841) species complex in the Paraná-Paraguay basin, with description of two new ocellated species (Chondrichthyes: Myliobatiformes: Potamotrygonidae). Neotrop. Ichthyol. 2013, 11, 693-737. 
19. Almeida, M.P.; Lins, P.M.; Charvet-Almeida, P.; Barthem, R.B. Diet of the freshwater stingray Potamotrygon motoro (Chondrichthyes: Potamotrygonidae) on Marajo Island (Para, Brazil). Braz. J. Biol. 2010, 70, 155-162.

20. Almeida, M.P.; Barthem, R.B.; da Silva Viana, A.; Charvet-Almeida, P. Factors affecting the distribution and abundance of freshwater stingrays (Chondrichthyes: Potamotrygonidae) at Marajó Island, mouth of the Amazon River. Pan Am. J. Aquat. Sci. 2009, 4, 1-11.

21. Halstead, B.W. Poisonous and Venomous Marine Animals of the World; United States Government Printing Office: Washington, DC, USA, 1970; Volume 3.

22. Charvet-Almeida, P.; Araújo, M.L.G.; Rosa, R.S.; Rincón, G. Neotropical freshwater stingray: Diversity and conservation status. Shark News 2002, 14, 47-51.

23. Haddad, V., Jr.; Neto, D.G.; de Paula Neto, J.B.; de Luna Marques, F.P.; Barbaro, K.C. Freshwater stingrays: Study of epidemiologic, clinic and therapeutic aspects based on 84 envenomings in humans and some enzymatic activities of the venom. Toxicon 2004, 43, 287-294.

24. Barbaro, K.C.; Lira, M.S.; Malta, M.B.; Soares, S.L.; Garrone Neto, D.; Cardoso, J.L.; Santoro, M.L.; Haddad Junior, V. Comparative study on extracts from the tissue covering the stingers of freshwater (Potamotrygon falkneri) and marine (Dasyatis guttata) stingrays. Toxicon 2007, 50, 676-687.

25. Pedroso, C.M.; Jared, C.; Charvet-Almeida, P.; Almeida, M.P.; Garrone Neto, D.; Lira, M.S.; Haddad, V., Jr.; Barbaro, K.C.; Antoniazzi, M.M. Morphological characterization of the venom secretory epidermal cells in the stinger of marine and freshwater stingrays. Toxicon 2007, 50, 688-697.

26. Magalhaes, M.R.; da Silva, N.J., Jr.; Ulhoa, C.J. A hyaluronidase from Potamotrygon motoro (freshwater stingrays) venom: Isolation and characterization. Toxicon 2008, 51, 1060-1067.

27. Garrone Neto, D.; Haddad, V., Jr. Arraias em rios da região Sudeste do Brasil: Locais de ocorrência e impactos sobre a população. Rev. Soc. Bras. Med. Trop. 2010, 43, 82-88.

28. Antoniazzi, M.M.; Benvenuti, L.A.; Lira, M.S.; Jared, S.G.; Neto, D.G.; Jared, C.; Barbaro, K.C. Histopathological changes induced by extracts from the tissue covering the stingers of Potamotrygon falkneri freshwater stingrays. Toxicon 2011, 57, 297-303.

29. Haddad, V., Jr. Atlas de Animais Aquáticos Perigosos do Brasil: Guia Médico de Identificação e Tratamento; Editora Roca: São Paulo, Brazil, 2000.

30. Junghanss, T.; Bodio, M. Medically important venomous animals: Biology, prevention, first aid, and clinical management. Clin. Infect. Dis. 2006, 43, 1309-1317.

31. Garrone Neto, D.; Haddad, V., Jr. Acidentes por raias. In Animais Peçonhentos no Brasil: Biologia, Clínica e Terapêutica dos Acidentes; Cardoso, J.L.C., França, F.O.D.S., Wen, F.H., Málaque, C.M.S.A., Haddad, V., Jr., Eds.; Sarvier: São Paulo, Brazil, 2009; pp. 295-305.

32. Pardal, P.P.O. Ictismo por arraia. In Animais Peçonhentos no Brasil: Biologia, Clínica e Terapêutica dos Acidentes; Sarvier: São Paulo, Brazil, 2009; pp. 523-529.

33. Lameiras, J.L.V.; Costa, O.T.F.; Santos, M.C.; Duncan, W.L.P. Arraias de água doce (Chondrichthyes_-Potamotrygonidae): Biologia, veneno e acidentes. Sci. Amazon. 2013, 2, 11-27.

34. Domingos, M.O.; Franzolin, M.R.; dos Anjos, M.T.; Franzolin, T.M.; Barbosa Albes, R.C.; de Andrade, G.R.; Lopes, R.J.; Barbaro, K.C. The influence of environmental bacteria in freshwater stingray wound-healing. Toxicon 2011, 58, 147-153.

35. Barber, G.R.; Swygert, J.S. Necrotizing fasciitis due to Photobacterium damsela in a man lashed by a stingray. N. Engl. J. Med. 2000, 342, 824. 
36. Torrez, P.P.; Quiroga, M.M.; Said, R.; Abati, P.A.; Franca, F.O. Tetanus after envenomations caused by freshwater stingrays. Toxicon 2015, 97, 32-35.

37. Clark, R.F.; Girard, R.H.; Rao, D.; Ly, B.T.; Davis, D.P. Stingray envenomation: A retrospective review of clinical presentation and treatment in 119 cases. J. Emerg. Med. 2007, 33, 33-37.

38. Haddad, V., Jr.; Cardoso, J.L.C.; Garrone Neto, D. Injuries by marine and freshwater stingray: History, clinical aspects of the envenomations and current status of a neglected problem in Brazil. J. Venom. Anim. Toxins Incl. Trop. Dis. 2013, 19, 1-10.

39. Diaz, J.H. The evaluation, management, and prevention of stingray injuries in travelers. J. Travel Med. 2008, 15, 102-109.

40. Rodrigues, R.J. Pharmacology of South American freshwater stingray venom (Potamotrygon motoro). Trans. N. Y. Acad. Sci. 1972, 34, 677-686.

41. Baumann, K.; Casewell, N.R.; Ali, S.A.; Jackson, T.N.; Vetter, I.; Dobson, J.S.; Cutmore, S.C.; Nouwens, A.; Lavergne, V.; Fry, B.G. A ray of venom: Combined proteomic and transcriptomic investigation of fish venom composition using barb tissue from the blue-spotted stingray (Neotrygon kuhlii). J. Proteomics 2014, 109, 188-198.

42. Sivan, G. Fish venom: Pharmacological features and biological significance. Fish Fish. 2009, 10, 159-172.

43. Conceicao, K.; Konno, K.; Melo, R.L.; Marques, E.E.; Hiruma-Lima, C.A.; Lima, C.; Richardson, M.; Pimenta, D.C.; Lopes-Ferreira, M. Orpotrin: A novel vasoconstrictor peptide from the venom of the Brazilian stingray Potamotrygon gr. orbignyi. Peptides 2006, 27, 3039-3046.

44. Conceicao, K.; Santos, J.M.; Bruni, F.M.; Klitzke, C.F.; Marques, E.E.; Borges, M.H.; Melo, R.L.; Fernandez, J.H.; Lopes-Ferreira, M. Characterization of a new bioactive peptide from Potamotrygon gr. orbignyi freshwater stingray venom. Peptides 2009, 30, 2191-2199.

45. Magalhaes, K.W.; Lima, C.; Piran-Soares, A.A.; Marques, E.E.; Hiruma-Lima, C.A.; Lopes-Ferreira, M. Biological and biochemical properties of the Brazilian Potamotrygon stingrays: Potamotrygon cf. scobina and Potamotrygon gr. orbignyi. Toxicon 2006, 47, 575-583.

46. Magalhães, M.R. Estudos Bioquímicos do Veneno de Raias Potamotrygon Motoro (Chondrichthyes: Dasyatidae, Potamotrygoninae)—Purificação e Caracterização de uma Hialuronidase; Dissertação de Mestrado, Instituto de Ciências Biológicas, Universidade Federal de Goiás: Goiânia, Goiás, Brasil, 2001.

47. Conceicao, K.; Monteiro-dos-Santos, J.; Seibert, C.S.; Silva, P.I., Jr.; Marques, E.E.; Richardson, M.; Lopes-Ferreira, M. Potamotrygon cf. henlei stingray mucus: Biochemical features of a novel antimicrobial protein. Toxicon 2012, 60, 821-829.

48. Kirchhoff, K.N.; Klingelhofer, I.; Dahse, H.M.; Morlock, G.; Wilke, T. Maturity-related changes in venom toxicity of the freshwater stingray Potamotrygon leopoldi. Toxicon 2014, 92, 97-101.

49. Monteiro-dos-Santos, J.; Conceicao, K.; Seibert, C.S.; Marques, E.E.; Silva, P.I., Jr.; Soares, A.B.; Lima, C.; Lopes-Ferreira, M. Studies on pharmacological properties of mucus and sting venom of Potamotrygon cf. henlei. Int. Immunopharmacol. 2011, 11, 1368-1377.

50. Hiemenz, J.W.; Kennedy, B.; Kwon-Chung, K.J. Invasive fusariosis associated with an injury by a stingray barb. J. Med. Vet. Mycol. 1990, 28, 209-213.

51. Ho, P.L.; Tang, W.M.; Lo, K.S.; Yuen, K.Y. Necrotizing fasciitis due to Vibrio alginolyticus following an injury inflicted by a stingray. Scand. J. Infect. Dis. 1998, 30, 192-193. 
52. Minnaganti, V.R.; Patel, P.J.; Iancu, D.; Schoch, P.E.; Cunha, B.A. Necrotizing fasciitis caused by Aeromonas hydrophila. Heart Lung J. Crit. Care 2000, 29, 306-308.

53. Miyoshi, S. Extracellular proteolytic enzymes produced by human pathogenic vibrio species. Front. Microbiol. 2013, 4, 339.

54. Mullins, J.F.; Wilson, C.J.; Best, W.C. Cryotherapy in the treatment of stingray wounds. South. Med. J. 1957, 50, 533-535.

55. Brisset, I.B.; Schaper, A.; Pommier, P.; de Haro, L. Envenomation by Amazonian freshwater stingray Potamotrygon motoro: 2 cases reported in Europe. Toxicon 2006, 47, 32-34.

56. Russell, F.E.; Lewis, R. Evaluation of the current status of therapy for stingray injuries. In Venoms; American Association for the Advancement of Science: Washington, DC, USA, 1956; pp. 43-53.

57. Russell, F.E.; Panos, T.C.; Kang, L.W.; Warner, A.M.; Colket, T.C., 3rd. Studies on the mechanism of death from stingray venom; a report of two fatal cases. Am. J. Med. Sci. 1958, 235, 566-584.

58. Evans, R.J.; Davies, R.S. Stingray injury. J. Accid. Emerg. Med. 1996, 13, 224-225.

59. Meyer, P.K. Stingray injuries. Wilderness Environ. Med. 1997, 8, 24-28.

60. Giltner, C.L.; Bobenchik, A.M.; Uslan, D.Z.; Deville, J.G.; Humphries, R.M. Ciprofloxacin-resistant Aeromonas hydrophila cellulitis following leech therapy. J. Clin. Microbiol. 2013, 51, 1324-1326.

61. Figueira, V.; Vaz-Moreira, I.; Silva, M.; Manaia, C.M. Diversity and antibiotic resistance of Aeromonas spp. in drinking and waste water treatment plants. Water Res. 2011, 45, 5599-5611.

62. Chu, D.T. Recent progress in novel macrolides, quinolones, and 2-pyridones to overcome bacterial resistance. Med. Res. Rev. 1999, 19, 497-520.

63. Chang, V.S.; Dhaliwal, D.K.; Raju, L.; Kowalski, R.P. Antibiotic Resistance in the Treatment of Staphylococcus aureus Keratitis: A 20-Year Review. Cornea 2015, 34, 698-703.

64. Huang, Y.; Ogutu, J.O.; Gu, J.; Ding, F.; You, Y.; Huo, Y.; Zhao, H.; Li, W.; Zhang, Z.; Zhang, W.; et al. Comparative analysis of quinolone resistance in clinical isolates of Klebsiella pneumoniae and Escherichia coli from Chinese children and adults. BioMed Res. Int. 2015, 2015, 168292.

65. Maleki, M.H.; Jalilian, F.A.; Khayat, H.; Mohammadi, M.; Pourahmad, F.; Asadollahi, K.; Pakzad, I.; Sadeghifard, N.; Soroush, S.; Emaneini, M.; et al. Detection of highly ciprofloxacin resistance acinetobacter baumannii isolated from patients with burn wound infections in presence and absence of efflux pump inhibitor. Maedica (Buchar) 2014, 9, 162-167.

66. Park, M.; Sutherland, J.B.; Kim, J.N.; Rafii, F. Effect of fluoroquinolone resistance selection on the fitness of three strains of Clostridium perfringens. Microb. Drug Resist. 2013, 19, 421-427.

67. Cohen, J.S. Peripheral neuropathy associated with fluoroquinolones. Ann. Pharmacother. 2001, $35,1540-1547$.

68. Jumma, O.K.; Dick, J.; Marshall, A.; Mellor, K. Ciprofloxacin induced acute small fibre neuropathy. Case report. Can. J. Neurol. Sci. 2013, 40, 127-128.

69. Samarakoon, N.; Harrisberg, B.; Ell, J. Ciprofloxacin-induced toxic optic neuropathy. Clin. Exp. Ophthalmol. 2007, 35, 102-104.

70. Ghatole, M.; Manthalkar, P.; Kandle, S.; Yemul, V.; Jahagirdar, V. Correlation of extended spectrum beta lactamases production with cephalosporin resistance in gram negative bacilli. Indian J. Pathol. Microbiol. 2004, 47, 82-84.

71. Chuang, Y.M.; Tseng, S.P.; Teng, L.J.; Ho, Y.C.; Hsueh, P.R. Emergence of cefotaxime resistance in Citrobacter freundii causing necrotizing fasciitis and osteomyelitis. J. Infect. 2006, 53, e161-e163. 
72. Brusselaers, N.; Vogelaers, D.; Blot, S. The rising problem of antimicrobial resistance in the intensive care unit. Ann. Intensive Care 2011, 1, 47.

73. Ko, W.C.; Wu, H.M.; Chang, T.C.; Yan, J.J.; Wu, J.J. Inducible beta-lactam resistance in Aeromonas hydrophila: Therapeutic challenge for antimicrobial therapy. J. Clin. Microbiol. 1998, 36, 3188-3192.

74. Harada, K.; Arima, S.; Niina, A.; Kataoka, Y.; Takahashi, T. Characterization of Pseudomonas aeruginosa isolates from dogs and cats in Japan: Current status of antimicrobial resistance and prevailing resistance mechanisms. Microbiol. Immunol. 2012, 56, 123-127.

75. Schechter, N.M. Structure of the dermal-epidermal junction and potential mechanisms for its degradation: The possible role of inflammatory cells. Immunol. Ser. 1989, 46, 477-507.

76. Paquet, P.; Nusgens, B.V.; Pierard, G.E.; Lapiere, C.M. Gelatinases in drug-induced toxic epidermal necrolysis. Eur. J. Clin. Investig. 1998, 28, 528-532.

77. Burns, E.H., Jr.; Marciel, A.M.; Musser, J.M. Structure-function and pathogenesis studies of Streptococcus pyogenes extracellular cysteine protease. Adv. Exp. Med. Biol. 1997, 418, 589-592.

78. Jackson, R.J.; Lim, D.V.; Dao, M.L. Identification and analysis of a collagenolytic activity in Streptococcus mutans. Curr. Microbiol. 1997, 34, 49-54.

79. Seddon, S.V.; Hemingway, I.; Borriello, S.P. Hydrolytic enzyme production by Clostridium difficile and its relationship to toxin production and virulence in the hamster model. J. Med. Microbiol. 1990, 31, 169-174.

80. Tytell, A.A.; Hewson, K. Production, purification, and some properties of Clostridium histolyticum collagenase. Proc. Soc. Exp. Biol. Med. 1950, 74, 555-558.

81. Smith, L.D. Virulence factors of Clostridium perfringens. Rev. Infect. Dis. 1979, 1, 254-262.

82. Rood, J.I. Virulence genes of Clostridium perfringens. Annu. Rev. Microbiol. 1998, 52, 333-360.

83. Diener, B.; Carrick, L., Jr.; Berk, R.S. In vivo studies with collagenase from Pseudomonas aeruginosa. Infect. Immun. 1973, 7, 212-217.

84. Wellisch, G.; Cohen, E.; Cahane, Z.; Horowitz, J. Simple method for collagenase determination in 38 Pseudomonas aeruginosa strains. J. Clin. Microbiol. 1984, 20, 1020-1021.

85. Reid, G.C.; Woods, D.R.; Robb, F.T. Peptone induction and rifampin-insensitive collagenase production by Vibrio alginolyticus. J. Bacteriol. 1980, 142, 447-454.

86. Hare, P.; Scott-Burden, T.; Woods, D.R. Characterization of extracellular alkaline proteases and collagenase induction in Vibrio alginolyticus. J. Gen. Microbiol. 1983, 129, 1141-1147.

87. Keil, B. Vibrio alginolyticus (“Achromobacter") collagenase: Biosynthesis, function and application. Matrix Suppl. 1992, 1, 127-133.

88. Takeuchi, H.; Shibano, Y.; Morihara, K.; Fukushima, J.; Inami, S.; Keil, B.; Gilles, A.M.; Kawamoto, S.; Okuda, K. Structural gene and complete amino acid sequence of Vibrio alginolyticus collagenase. Biochem. J. 1992, 281, 703-708.

89. Xiong, P.; Peng, X.; Wei, S.; Chen, Y.; Zhao, H.; Tang, S.; Wu, X. Virulence-related genes of Vibrio alginolyticus and its virulence in mice. Wei Sheng Wu Xue Bao 2014, 54, 80-88.

(C) 2015 by the authors; licensee MDPI, Basel, Switzerland. This article is an open access article distributed under the terms and conditions of the Creative Commons Attribution license (http://creativecommons.org/licenses/by/4.0/). 